\title{
Particles released by abused prismatic Ni-rich automotive lithium-ion batteries
}

\author{
HEWU WANG \\ State Key Laboratory of Automotive Safety and Energy \\ Tsinghua University \\ Haidian District, Beijing \\ P. R. CHINA \\ wanghw@tsinghua.edu.cn \\ YAJUN ZHANG \\ State Key Laboratory of Automotive Safety and Energy \\ Tsinghua University \\ Haidian District, Beijing \\ P. R. CHINA \\ zhyj032469@163.com \\ WEIFENG LI \\ State Key Laboratory of Automotive Safety and Energy \\ Tsinghua University \\ Haidian District, Beijing \\ P. R. CHINA \\ $\underline{\text { lwfsearch@126.com }}$ \\ CHENG LI \\ State Key Laboratory of Automotive Safety and Energy \\ Tsinghua University \\ Haidian District, Beijing \\ P. R. CHINA \\ 2317351211@qq.com \\ MINGGAO OUYANG \\ State Key Laboratory of Automotive Safety and Energy \\ Tsinghua University \\ Haidian District, Beijing \\ P. R. CHINA \\ ouymg@tsinghua.edu.cn
}

\begin{abstract}
The particulate matter released by lithium-ion batteries during eruption and combustion caused by thermal runaway may contain heavy metal pollution elements. The aim of this study is to reveal four heavy metal element content and size distribution of particulate matter released by abused prismatic Ni-rich automotive lithium-ion batteries. A fully charged commercial $50 \mathrm{Ah} \mathrm{Li}\left(\mathrm{Ni}_{0.6} \mathrm{Mn}_{0.2} \mathrm{Co}_{0.2}\right) \mathrm{O}_{2}$ cell was triggered by

heating in a sealed chamber at nitrogen environment. The particulate matter with size being below $500 \mu_{\mathrm{m}}$ were divided into three samples using sieves. Four soil pollution elements, including nickel, copper, zinc, chromium, were detected, and sizes were analyzed. The results show that all these four elements are found, and nickel and copper are found in all samples. Among the four elements, Ni had the largest mass percentage, followed by $\mathrm{Cu}$, $\mathrm{Zn}$ and $\mathrm{Cr}$. These particulate matter account for $1.7 \%$ of the cell mass, with the minimum size and median size being approximately $1.45 \mu \mathrm{m}$ and $162.9 \mathrm{um}$. The element content reveals the pollution from LIBs and the size distribution provides a basis for the design of the particle filter pore.
\end{abstract}

Key-Words: lithium-ion batteries, settleable particulate matter, heavy metal element, particle size 


\section{Introduction}

In recent years, regulatory restrictions on emissions and environmental awareness have prompted a surge in zero or partial-aero emission electric vehicles, which including battery electric vehicles (BEV) and plug-in hybrid electric vehicles (PHEV), and have led to reductions in the usage of traditional petroleum internal combustion engine vehicles, which including gasoline and diesel vehicles [1-5]. Electric car deployment has been growing rapidly over the past ten years, with the global stock of electric passenger cars passing 5 million in 2018, an increase of $63 \%$ from the previous year [6].

However, when a fire occurs in a BEV or PHEV, similar to a traditional petroleum vehicle, it also causes pollution to the environment [7-9]. Amandine. et al [7] compared the fire consequences of BEV and the corresponding gasoline vehicle and found that the cumulative masses of carbon dioxide $\left(\mathrm{CO}_{2}\right)$, carbon monoxide $(\mathrm{CO})$, total hydrocarbons, nitric oxide (NO), nitrogen dioxide $\left(\mathrm{NO}_{2}\right)$, hydrogen chloride $(\mathrm{HCl})$ and hydrogen cyanide $(\mathrm{HCN})$ were similar for both types of vehicles. The types of toxic gases released by BEV and gasoline vehicle in fires were similar, including $\mathrm{CO}, \mathrm{HCl}$ and $\mathrm{HF}$ [7-9], but cumulative mass of $\mathrm{HF}$ was higher for $\mathrm{BEV}$ due to the combustion of the Li-ion battery pack [7].

Because the main difference between electric vehicles and petroleum vehicles is the power system, it is necessary to focus on the environmental pollution of electric vehicle power systems in the event of a fire accident. After many years of development, lithium-ion batteries (LIBs) have become increasingly acceptable as one of the main electricity storage sources in vehicles due to their largely increasing in energy density, calendar or cycle life, and reliability [10].

The LIB releases various gases during the eruption and combustion processes [11-19]. These gases primarily form from the decomposition of negative solid-electrolyte interface film [11, 12], reactions between the anodes and electrolytes [11], decomposition of cathode materials [11 28, 13-15], decomposition of electrolytes [16], decomposition of binders [17], and reactions between various material decomposition products. Somandepalli et al. [18] studied variations in the composition, concentration, and volume of these gas during eruption under different SOCs. They placed the battery in a sealed 6-L chamber filled with argon
(Ar) and heated it until vent. The results showed that gases erupted mainly included carbon dioxide $\left(\mathrm{CO}_{2}\right)$, carbon monoxide $(\mathrm{CO})$, hydrogen $\left(\mathrm{H}_{2}\right)$, and hydrocarbons with different numbers of carbon atoms such as methane $\left(\mathrm{CH}_{4}\right)$, ethylene $\left(\mathrm{C}_{2} \mathrm{H}_{4}\right)$, and ethane $\left(\mathrm{C}_{2} \mathrm{H}_{6}\right)$. As the SOC increased, the $\mathrm{CO}_{2}$ concentration decreased, the $\mathrm{CO}$ and $\mathrm{CH}_{4}$ concentrations increased, the $\mathrm{H}_{2}$ concentration remained relatively unchanged, and total hydrocarbons varied between $20 \%$ and $30 \%$. Perrine et al. [19] found $\mathrm{CO}_{2}, \mathrm{CO}, \mathrm{THC}, \mathrm{NO}, \mathrm{SO}_{2}, \mathrm{HCl}$ and $\mathrm{HF}$ in the emissions of 2.9 Ah pouch type batteries during combustion.

Regarding the PM released by LIBs, researchers are more concerned about their impact on fire. With gases, these PM are released from the inside of the battery with the eruption flow. These hightemperature $\mathrm{PM}$ are often accompanied by sparks with temperatures as high as $1,200^{\circ} \mathrm{C}$ [20]. Once the combustible mixture and high-temperature PM have been simultaneously released into the external environment and exposed to oxygen, fire or even explosion could occur according to the combustion theory [20]. In addition, because high-temperature particulate has large kinetic energy, it is easily scattered and exposed to combustible materials, making it vulnerable to catching fire.

Few studies reported soil pollution caused by particulate matter released by lithium-ion batteries $[21,22]$. Soil environmental quality affects directly the quality of arable land, the safety of agricultural products and the health of the human environment. Soil heavy metal pollution has been one of the major environmental issues facing countries around the world [23-25]. As soil environmental issues become more prominent and public awareness of environmental protection increases, China's work on soil environmental protection is getting heavier. National Survey of Soil Pollution in China's Ministry of Ecology and Environment reported that heavy metal pollution elements in China's soil mainly include nickel (Ni), copper (Co), zinc ( $\mathrm{Zn})$, chromium $(\mathrm{Cr})$, cadmium $(\mathrm{Cd})$, mercury $(\mathrm{Hg})$, lead $(\mathrm{Pb})$ and $\operatorname{arsenic}(\mathrm{As})[26,27]$.

Since the LIB material contains a variety of metal elements [9], such as nickel (Ni), Co, manganese $(\mathrm{Mn})$ and other metal elements. The particulate matter (PM) released by lithium-ion batteries (LIBs) during eruption and combustion may contain these elements and pollute the soil. For example, when an electric car fire caused by thermal 
runaway of a LIB occurs, PM vented by the battery during the firefighting process may be released directly or with the water to the surrounding environment and deposited in the soil. They can be enriched thousands of times by biomagnification of the food chain before they finally enter the human body [28].

LIBs probably will be one of heavy metal soil pollution element sources in the future due to their large-scale application on vehicles and an increasing number of electric vehicle fires.

In our previous research $[21,22]$, the composition of the PM released by a LIB was given in a relatively macroscopic view. A fully charged commercial 50 Ah $\mathrm{Li}\left(\mathrm{Ni}_{0.6} \mathrm{Mn}_{0.2} \mathrm{Co}_{0.2}\right) \mathrm{O}_{2}$ cell was triggered by heating in a sealed chamber. The main elements were carbon, nickel, cobalt, etc. The content of metallic elements was approximately $40 \%$. The emissions also contained potentially toxic elements, including aluminum, lithium, fluorine, etc. However, the content of soil pollution elements in the small particles was not given. Small particles are more likely to enter the natural environment and it is more difficult to suppress them. Therefore, soil pollution elements in small particles need to be studied. In addition, the common method of trapping PM is to use microporous filtration, so it is necessary to study the size of these PM.

It should be noted that the release of particulate matter by lithium-ion batteries is an accidental event, and there is a large difference in the magnitude of continuous release of particulate matter under normal operating conditions of traditional vehicles.

The aim of this study is to reveal four heavy metal element content and size distribution of vent PM from abused prismatic Ni-rich automotive lithium-ion batteries. With this in mind, a $50 \mathrm{Ah}$, $3.65 \mathrm{~V}$, commercial prismatic LIB cell with lithium nickel manganate cobalt (NMC) oxide cathode at $100 \%$ SOC was used, and it was placed in a sealed chamber and heated by a $1 \mathrm{~kW}$ heater to trigger the thermal runaway. At the termination of the experiment, the PM scattered throughout the sealed chamber during the battery eruption caused by thermal runaway were collected. The settleable PM with size below $500 \mu \mathrm{m}$ were divided into three samples - $\mathrm{a}, \mathrm{b}$ and $\mathrm{c}-$ with sizes ranging from $0-50$ $\mu \mathrm{m}, 50-100 \mu \mathrm{m}$, and $100-500 \mu \mathrm{m}$, respectively. The $\mathrm{Ni}, \mathrm{Co}, \mathrm{Zn}$, and $\mathrm{Cr}$ content and size distribution were measured. These results will reveal the potential harm of the settleable PM released by LIBs to the soil.

\section{Experimental Procedure}

\subsection{Experimental setup}

A commercial cell based on NMC cathodes was tested, which is especially for electric automotive. According to the manufacturer's data, the cell nominal capacity and voltage is $50 \mathrm{Ah}$ and $3.65 \mathrm{~V}$, respectively. More information is shown in Table 1. The cell was composed of a lid, a shell and a core. The safety valve, tab and terminal of the cell were installed on the lid. The cathode, separator, and anode were curled to form the core. The cathode was composed of a cathode active material and a cathode current collector. The cathode active material of the cell in this research was mainly $\mathrm{Li}$ $\left(\mathrm{Ni}_{0.6} \mathrm{Mn}_{0.2} \mathrm{Co}_{0.2}\right) \mathrm{O}_{2}$, and the current collector was an aluminum foil. Similarly, the anode was composed of an anode active material and the anode current collector. The anode active material of the cell in this research was mainly graphite, and the current collector was a copper foil.

Table 1 Detailed technical specifications of the test cell.

\begin{tabular}{|l|l|}
\hline \multicolumn{1}{|c|}{ Parameters } & \multicolumn{1}{c|}{ Specifications } \\
\hline Cell mass $(\mathrm{g})$ & 900 \\
\hline Nominal capacity $(\mathrm{Ah})$ & 50 \\
\hline Nominal voltage $(\mathrm{V})$ & 3.65 \\
\hline Minimum voltage $(\mathrm{V})$ & 2.75 \\
\hline Maximum voltage $(\mathrm{V})$ & 4.25 \\
\hline Cathode active material & $\mathrm{Li}\left(\mathrm{Ni}_{0.6} \mathrm{Mn}_{0.2} \mathrm{Co}_{0.2}\right) \mathrm{O}_{2}$ \\
\hline $\begin{array}{l}\text { Cathode coating thickness } \\
(\mu \mathrm{m})\end{array}$ & 61 \\
\hline Anode active material & $\mathrm{Graphite}$ \\
\hline $\begin{array}{l}\text { Anode coating thickness } \\
(\mu \mathrm{m})\end{array}$ & 73 \\
\hline Cathode current collector & Aluminum foil \\
\hline $\begin{array}{l}\text { Cathode current collector } \\
\text { thickness }(\mu \mathrm{m})\end{array}$ & 16 \\
\hline Anode current collector & Copper foil \\
\hline $\begin{array}{l}\text { Anode current collector } \\
\text { thickness }(\mu \mathrm{m})\end{array}$ & 10 \\
\hline Shell Material & Aluminium alloy \\
\hline
\end{tabular}

The thermal runaway was triggered by a heater. During the experiment, the cell was placed above the heater and fixed, as shown in Fig. 1. In order to ensure safety and collect the settleable PM released by the cell, the thermal runaway experiment was conducted in a self-made sealed chamber. Using this device, we have conducted studies on the eruption process, the identifications of LIB gas emissions at inert atmosphere and LIB particulate matter emissions at air atmosphere [21, 22, 29]. The air in 
the chamber can be replaced by nitrogen $\left(\mathrm{N}_{2}\right)$. To observe the vent PM during thermal runaway of the cell, a visualization window was installed in the wall of the sealed chamber. The outer surface of the sealed chamber was covered with insulating cotton to reduce heat transfer.

\subsection{Experimental methods}

The cell SOC for this research was set to $100 \%$, which is the most typical operation. The cell was fully charged under standard conditions before the test was started. The experiment consisted of the following steps. The cell underwent an open circuit voltage check, was charged to the selected SOC, then placed on top of the heater and fixed with hard refractory cottons. The heater was attached inside the sealed chamber and then the air in the chamber was replaced with $\mathrm{N}_{2}$. The thermal runaway experiment was initiated by turning on the heater. The cell inside the chamber was heated with a heating power of $5 \mathrm{~kW}$. The cell transited into thermal runaway and PM were released alone with the ejection flow.

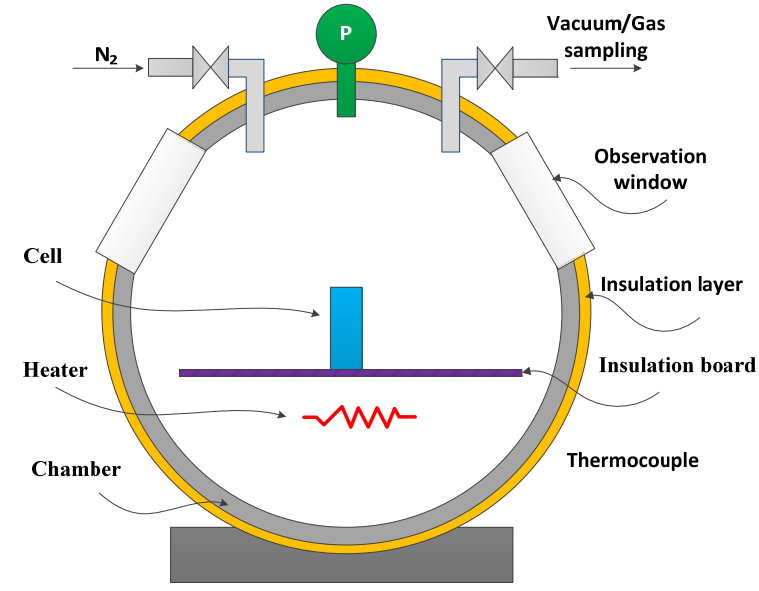

Fig. 1. Schematic diagram of the experimental setup [21, 22, 29].

All settleable PM in the chamber were collected after the thermal runaway reaction. The PM with size being below $500 \mu \mathrm{m}$ was selected by a sieve. To get the mass distribution, these PM were divided into 5 samples by filters with mesh diameter of 30 $\mu \mathrm{m}, 50 \mu \mathrm{m}, 100 \mu \mathrm{m}$, and $250 \mu \mathrm{m}$, as shown in Fig. 2. Then they were divided into three samples $(a, b$, and c), with the sizes ranging from $0-50 \mu \mathrm{m}, 50$ $100 \mu \mathrm{m}$, and $100-500 \mu \mathrm{m}$ to detect the element content. It should be noted that the threshold for each sample is determined based on the classification of soil particles [30], shown as Table 2. The size below $50 \mu \mathrm{m}$ was defined as silt and clay, between $50 \sim 100 \mu \mathrm{m}$ was defined as very fine sand, between 100 250 $\mu \mathrm{m}$ was defined as fine sand, and between 250 500 $\mu \mathrm{m}$ was defined as medium sand.

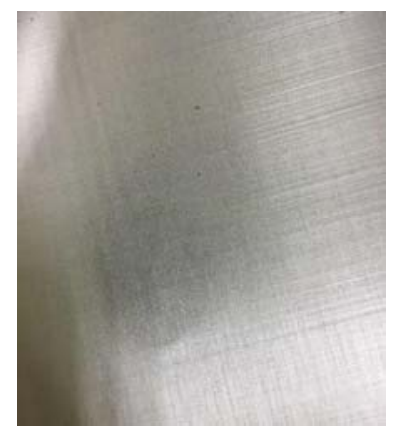

$0 \sim 30 \mu \mathrm{m}$

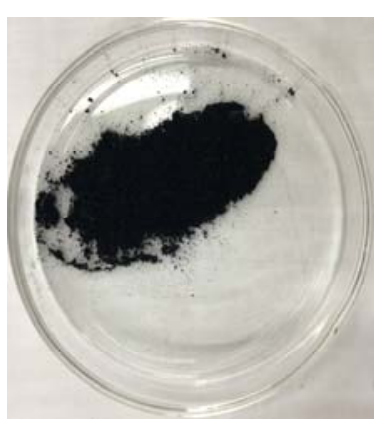

$30 \sim 50 \mu \mathrm{m}$

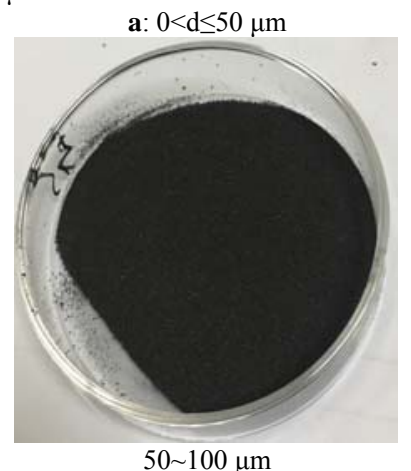

$50<\mathrm{d}<100 \mu \mathrm{m}$

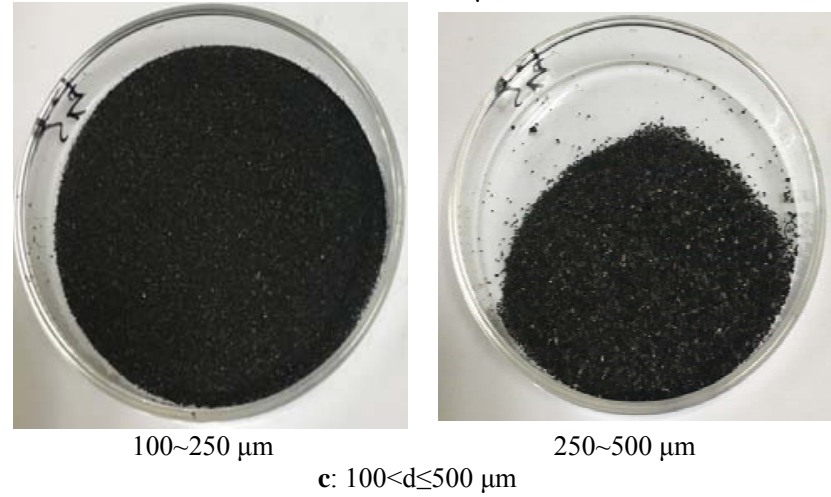

Fig. 2. Photograph of samples.

Table 2 Partial soil particle classification method.

\begin{tabular}{|c|c|}
\hline Size interval $(\boldsymbol{\mu m})$ & Classification \\
\hline$<50$ & Silt and clay \\
\hline $50^{\sim} 100$ & Very fine sand \\
\hline $100^{\sim} 250$ & Fine sand \\
\hline $250 \sim 500$ & Medium sand \\
\hline
\end{tabular}

The mass was detected by a million-point electronic balance (Sartorius, Germany; BSA224S). The particle size distribution was analyzed by a Malvern particle size analyzer (Malvern Panalytical, United Kingdom; Hydro2000MU). The Ni, Co, Zn, and $\mathrm{Cr}$ content were detected by an inductively coupled plasma mass spectrometer (Thermo Fisher Scientific., America; ICP-6000). The inductively coupled plasma mass spectrometry are widely used methods and have high precision. The Analysis and detection process were shown as Fig. 3. 


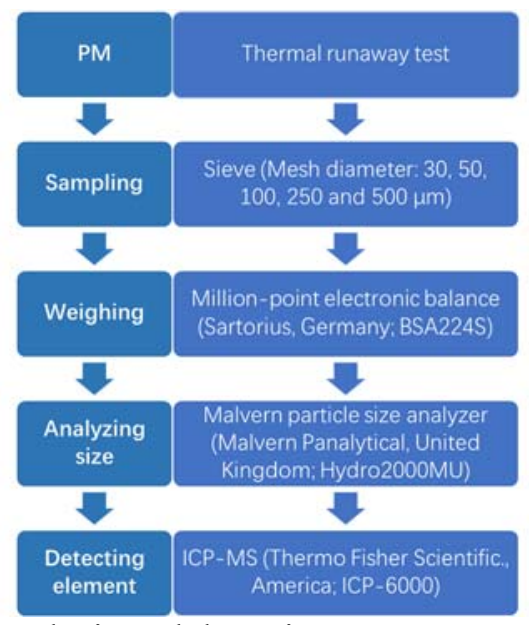

Fig. 3. Analysis and detection process.

\section{Results and Discussion}

\subsection{Element Content}

Table 3 shows the content of the four elements, including $\mathrm{Ni}, \mathrm{Cu}, \mathrm{Zn}$ and $\mathrm{Cr}$, in these three samples. The role of the four elements in the battery is as follows [31]. $\mathrm{Ni}$ mainly comes from $\mathrm{Li}$ $\left(\mathrm{Ni}_{0.6} \mathrm{Mn}_{0.2} \mathrm{Co}_{0.2}\right) \mathrm{O}_{2}$, which is the cathode material of the battery. This positive electrode material is a layered crystal. During the charging process, lithium ions can be de-intercalated from the crystal, and the metal ions in the positive electrode material undergo an oxidation reaction due to the principle of electrical neutrality, and the valence state increases. During discharge, lithium ions are released from the negative electrode to the positive electrode and reembedded in the crystal. At the same time, the metal ions undergo a reduction reaction and the valence state decreases. The development of positive electrode materials is to increase nickel, because increasing the content of $\mathrm{Ni}$ helps to increase the capacity of the battery, and $\mathrm{Ni}$ is cheaper. $\mathrm{Cu}$ comes mainly from the negative current collector of the battery. The current collector is the base metal used to attach the active material. The current collector is in contact with the active material, and its function is to collect the current generated by the active material and output the current to the outside. The negative electrode current collector generally uses copper foil. Copper foil is generally required to have electron conduction and very stable electrochemical characteristics. Because the organic electrolyte used in lithium ion batteries is highly corrosive, copper foils are required to have strong corrosion resistance. In addition, the copper foil surface must ensure good adhesion to the negative electrode material, and the tensile strength must be sufficiently high. $\mathrm{Zn}$ and $\mathrm{Cr}$ are mainly derived from additives. The role of additives is mainly to improve battery performance.

To describe the contents of these elements in each sample clearly, these four elements are classified according to their mass percentages, i.e. the overall mass percentage, from high to low, above $1 \%$ as shown in Fig. 4(a), and below 1\% as shown in Fig. 4(b).

As shown in Fig. 4(a), the constituent elements with an overall mass percentage of more than $1 \%$ include $\mathrm{Ni}$, and $\mathrm{Cu}$, which account for $41.422 \%$, and $6.537 \%$, respectively. The content of nickel is about 7 times that of copper. As shown in Fig. 4(b), the constituent elements with an overall mass percentage below $1 \%$ are $\mathrm{Zn}$, and $\mathrm{Cr}$, and both corresponding percentages are $0.002 \%$.

Table 3 Elemental mass percentage in each sample.

\begin{tabular}{|c|c|c|c|c|}
\hline & Overall & $\mathbf{a}$ & $\mathbf{b}$ & $\mathbf{c}$ \\
\cline { 2 - 5 } & $\mathbf{0}<\mathbf{d} \leqslant \mathbf{5 0 0}$ & $\mathbf{0}<\mathbf{d} \leqslant \mathbf{5 0}$ & $\begin{array}{c}\mathbf{5 0}<\mathbf{d} \leqslant \\
\mathbf{1 0 0}\end{array}$ & $\begin{array}{c}\mathbf{1 0 0}<\mathbf{d} \leqslant \\
\mathbf{5 0 0}\end{array}$ \\
\hline $\mathrm{Ele.}$ & $\mathbf{( \% )}$ & $\mathbf{( \% )}$ & $\mathbf{( \% )}$ & $\mathbf{( \% )}$ \\
\hline $\mathrm{Ni}$ & 41.422 & 41.725 & 38.050 & 44.142 \\
\hline $\mathrm{Cu}$ & 6.537 & 11.208 & 6.502 & 5.776 \\
\hline $\mathrm{Zn}$ & 0.002 & 0.000 & 0.005 & 0.000 \\
\hline $\mathrm{Cr}$ & 0.002 & 0.000 & 0.001 & 0.003 \\
\hline
\end{tabular}
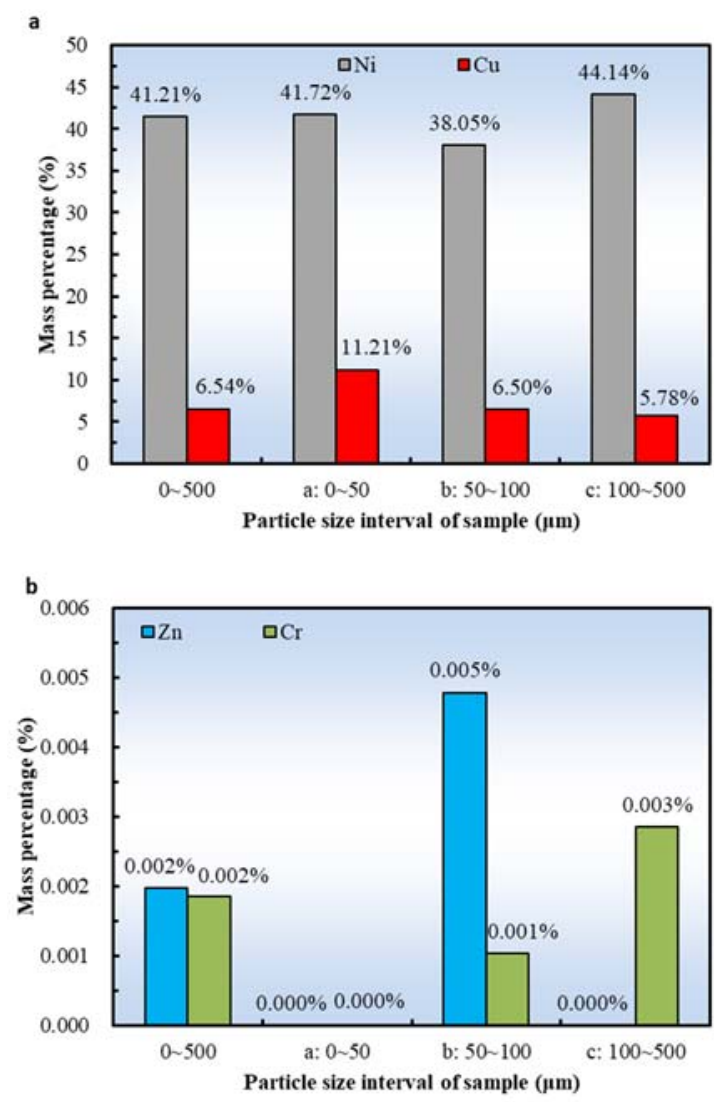

Fig. 4. Elemental composition of each sample. 
Among the four samples, sample a has the smallest size of PM, followed by samples b and c, and sample $d$ is the largest. The content of each element has different trend with increasing particle size. As the particle size increases, the Ni content increases first and then increases, the $\mathrm{Cu}$ content increases monotonically. The $\mathrm{Zn}$ has an opposite trend with $\mathrm{Ni}$, and $\mathrm{Cr}$ has an opposite trend with $\mathrm{Cu}$ with increasing particle size, as shown in Fig. 4.

These PM are mainly derived from the internal material of the cell, so the correspondence between the PM and cell parts can be established depending on the element source. $\mathrm{Ni}$ and $\mathrm{Cu}$ are mainly from the cathode active material and anode current collector, resulting that they have relatively high mass percentage in the PM. $\mathrm{Zn}$ and $\mathrm{Cr}$ are from the cathode material additives, so their contents are lower than those of $\mathrm{Ni}$ and $\mathrm{Cu}$.

It should be noted that soil polluted by heavy metals will affect crop growth and reduce production [27]. Crops may absorb and enrich certain pollutants and affect the quality of agricultural products. The loss of China's annual agricultural output reduction caused by heavy metal soil pollution reaches 20 billion yuan [27]. Soil pollution affects the survival and reproduction of plants, soil animals and microorganisms, and endangers normal soil ecological processes and ecosystem service functions [27]. Pollutants in the soil may undergo transformation and migration, and then enter surface water, groundwater, and the atmospheric environment, affecting the quality of surrounding environmental media. In addition, these elements can be enriched thousands of times by biomagnification of the food chain before they finally enter the human body [28]. Although elements such as $\mathrm{Ni}, \mathrm{Cu}, \mathrm{Cr}$ and $\mathrm{Zn}$ are necessary elements for plant growth and human nutrition, they can also cause harm to animals and humans at high concentrations [32]. The higher incidence of liver cancer in the Yangtze River Delta region of China is related to the high levels of $\mathrm{Cu}$ and $\mathrm{Zn}$ in soil, water and food [33]. The incidence of esophageal cancer in Henan, Shanxi, and other places in China is also related to the high content of $\mathrm{Cu}, \mathrm{Zn}, \mathrm{V}$, and $\mathrm{Zr}$ in the soil of the affected area. There is a clear relationship between trace element imbalances and high incidence of regional tumors [32].

Therefore, the PM released by the LIB after the thermal runaway must be collected and treated to avoid entering the ecological environment, such as water and soil. It is necessary to capture these PM. One of the methods is to use a particle filter. The pore size of the particle filter needs to be determined based on the size distribution of the particle size, shown as in 3.2 section.

\subsection{Size Distribution}

Fig. 5 shows variation in mass vs. particle size interval. The total mass of these PM is $14.57 \mathrm{~g}$, accounting for $1.67 \%$ of the cell mass, wherein PM with size being $0 \sim 30 \mu \mathrm{m}, 30 \sim 50 \mu \mathrm{m}, 50 \sim 100 \mu \mathrm{m}$, $100 \sim 250 \mu \mathrm{m}$, and $250 \sim 500 \mu \mathrm{m}$ accounted for $0.005 \%, 8.477 \%, 41.288 \%, 34.456 \%$ and $15.774 \%$ respectively. The results show that if a filter with a pore size below $100 \mu \mathrm{m}$ is used, more than $50 \%$ in mass of the particle with size below $500 \mu \mathrm{m}$ will be filtered.

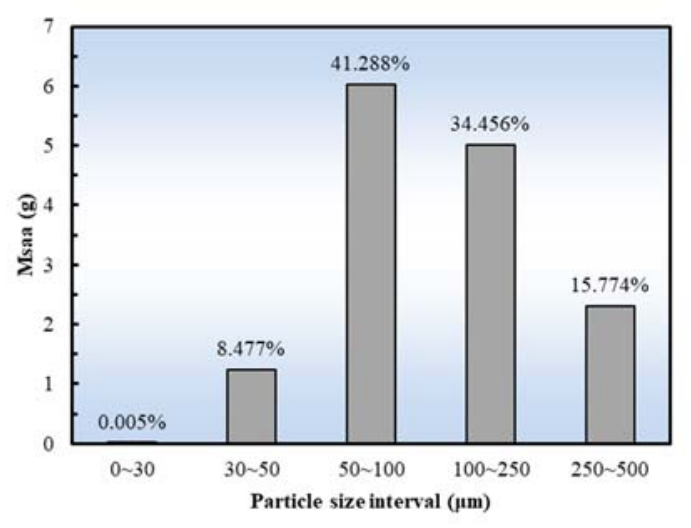

Fig. 5. Schematic diagram of the experimental setup.

Fig. 6 shows the particle size distribution of the settleable particle with size below $500 \mu \mathrm{m}$. The measuring lower range is $0.1 \mu \mathrm{m}$, and the minimum diameter of the particle is $1.45 \mu \mathrm{m}$. As the particle equivalent particle size increases, the particle volume first increases, then decreases, peaking at $198.5 \mu \mathrm{m}$ of the equivalent particle size. The D10 value is $43.8 \mu \mathrm{m}$, i.e., PM with an equivalent particle diameter of less than $43.8 \mu \mathrm{m}$ account for $10 \%$ of the total volume of the PM. Similarly, D50 and D90 are $162.9 \mu \mathrm{m}$ and $485.6 \mu \mathrm{m}$, respectively. The above results indicate that $90 \%, 50 \%$, and $10 \%$ of the PM can be filtered when sample a is filtered using filter holes with diameters of $485.6 \mu \mathrm{m}, 162.9$ $\mu \mathrm{m}$, and $43.8 \mu \mathrm{m}$, respectively. 


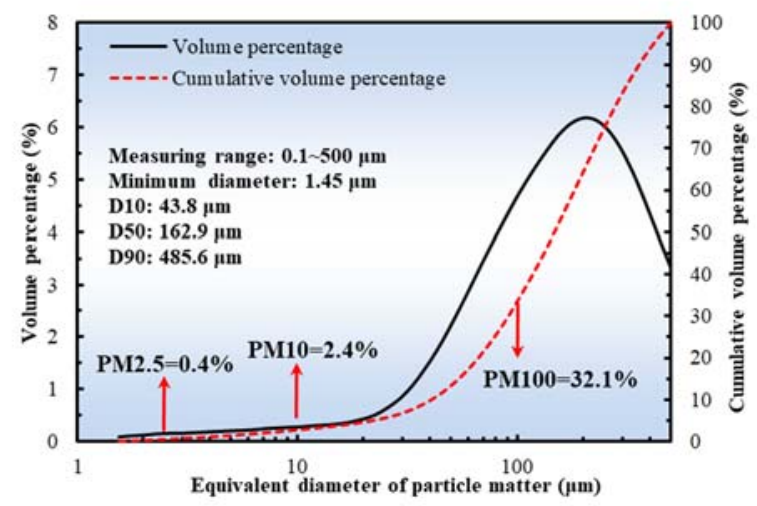

Fig. 6. Schematic diagram of the experimental setup.

\subsection{Contribution of this research}

The academic and engineering significance of the research are as follows:

There are currently very few literatures reporting the characteristics of battery PM emissions. This study gives and four heavy metal element content, the mass distribution and particle-size distribution of the settleable PM emissions with size below 500 $\mu \mathrm{m}$. The results of the study tell us that electric vehicles not only have safety problems, such as fire, but also potential harm to the ecological environment. This is because once the soil is contaminated, the surrounding farmland, animals, and people will be harmed, and the contaminated soil will be difficult to treat. In addition, once these heavy metal-containing particles enter the water environment, they are more harmful due to the fluidity of the water. Therefore, in the long run, the legislative branch should pay attention to this. This study provides a theoretical basis for further standardizing electric vehicle regulations and can also provide guidance for the rational disposal of lithium-ion battery particles.

\section{Conclusions}

The elemental composition and size distribution of the settleable solid PM with size being below 500 $\mu \mathrm{m}$ released by a $50 \mathrm{Ah}$ lithium-ion battery with an NMC cathode during thermal runaway were studied. The main conclusions are summarized as follows:

1) Among the four elements, Ni had the largest mass percentage, followed by $\mathrm{Cu}$, and then $\mathrm{Zn}$ and $\mathrm{Cr}$, with corresponding mass percentages of $41.422 \%, \quad 6.537 \%, \quad 0.002 \%$ and $0.002 \%$, respectively.
2) The mass percentage of each element had different trend with increasing particle size.

3) The mass of PM with size being below 500 $\mu \mathrm{m}$ was $14.57 \mathrm{~g}$, accounting for $1.67 \%$ of the cell mass, wherein PM with size being $0 \sim 30 \mu \mathrm{m}, 30 \sim 50$ $\mu \mathrm{m}, 50 \sim 100 \mu \mathrm{m}, 100 \sim 250 \mu \mathrm{m}$, and $250 \sim 500 \mu \mathrm{m}$ accounted for $0.005 \%, 8.477 \%, 41.288 \%, 34.456 \%$ and $15.774 \%$ respectively.

4) The minimum diameter of the settleable PM was $1.45 \mu \mathrm{m}$. The particle volume first increased, then decreased with increasing particle size, peaking at $198.5 \mu \mathrm{m}$. The D10, D50 and D90 value was 43.8 $\mu \mathrm{m}, 162.9 \mu \mathrm{m}$ and $485.6 \mu \mathrm{m}$, respectively.

\section{Acknowledgment}

This research was supported by the Ministry of Science and Technology of the People's Republic of China under the Grant No. 2016YFE0102200 and 2019YFE0100200, the China Postdoctoral Science Foundation under the Grant No. 2018M631464, and the National Natural Science Foundation of China under the Grant No. U1564205.

\section{References:}

[1] Xuebing Han, Languang Lu, Yuejiu Zheng, Xuning Feng, Zhe Li, Jianqiu Li, Minggao Ouyang. A review on the key issues of the lithium ion battery degradation among the whole life cycle. eTransportation 1 (2019) 100005.

[2] Minggao Ouyang. Meet the new era of new energy intelligent electric vehicles. Science and technology review 2019, 37 (7): 1-1.

[3] Graham Mills, Iain MacGill. Assessing electric vehicle storage, flexibility, and distributed energy resource potential. Journal of Energy Storage, 2018, 17: 357-366.

[4] Xiao Shi, Jian Pan, Hewu Wang, Hua Cai. Battery electric vehicles: What is the minimum range required? Energy 2019, 166: 352-358.

[5] Korakianitis T, Namasivayam AM, Crookes RJ. Natural-gas fueled spark-ignition (SI) and compression-ignition $(\mathrm{CI})$ engine performance and emissions. Prog Energy Combust Sci 2011, 37: $89-112$.

[6] IEA, Global Electric Vehicle (EV) Outlook 2019. https://www.iea.org/reports/global-evoutlook-2019/.

[7] Amandine Lecocq, Marie Bertana, Benjamin Truchot, Guy Marlair. Comparison of the fire consequences of an electric vehicle and an internal combustion engine vehicle. 2. International Conference on Fires In Vehicles - 
FIVE 2012, Sep 2012, Chicago, United States. SP Technical Research Institute of Sweden. Boras, pp.183-194, 2012.

[8] Masashi Takahashi, Masayuki Takeuchi, Kiyotaka Maeda, and Shouma Nakagawa. Comparison of Fires in Lithium-Ion Battery Vehicles and Gasoline Vehicles, 2014-01-0428.

[9] Yajun Zhang, Hewu Wang, Xuning Feng, Minggao Ouyang, Anjian Zhou, Ling Su, Huiqian Yang. Research progress on thermal runaway combustion characteristics of power lithiumion batteries, Journal of Mechanical Engineering, 55(20): 17-27.

[10] Z. Wang, F. Sun, P. Liu, Electric vehicle battery systems, China machine press, Beijing, 2017.

[11] R. Spotnitz, J. Franklin, Abuse behavior of high-power, lithium-ion cells, J. Power Sources 113 (2003) 81-100.

[12] M.N. Richard, J.R. Dahn, Accelerating rate calorimetry study on the thermal stability of lithium intercalated graphite in electrolyte. I. Experimental, Fuel Energ. Abs. 41 (1999) 2068-2077.

[13] H. Wang, A. Dang, K. Huang, Oxygen evolution in overcharged LixNi1/3Co1/3Mn1/3O2 electrode and its thermal analysis kinetics, Hubei Elec. Power 29 (2011) 1583-1588.

[14] D.D. MacNeil, J.R. Dahn, The reaction of charged cathodes with nonaqueous solvents and electrolytes: I. Li0.5CoO2. J. Electrochem. Soc. 148 (2001) A1205-A1210.

[15] Q. Wang, J. Sun, C. Chen, Thermal stability of delithiated with electrolyte for lithium-ion batteries, J. Electrochem. Soc. 154 (2007) A263-A267.

[16] S.E. Sloop, J.K. Pugh, S. Wang, J.B. Kerr, K. Kinoshita, Chemical reactivity of PF5 and LiPF6 in ethylene carbonate/dimethyl carbonate solutions, Electrochem. Solid St. 4 (2001) 357-364.

[17] A.D. Pasquier, F. Disma, T. Bowmer, A.S. Gozdz, G. Amatucci, J.M. Tarascon, Differential scanning calorimetry study of the reactivity of carbon anodes in plastic Li-ion batteries, J. Electrochem. Soc. 145 (1998) 472477.

[18] V. Somandepalli, K. Marr, Q. Horn, Quantification of combustion hazards of thermal runaway failures in lithium-ion batteries, SAE Int. J. Alt. Power. 3 (2014) 98104.

[19] Perrine Ribiere,Sylvie Grugeon,Mathieu Morcrette,Simeon Boyanov,Stphane Laruelle and Guy Marlair. Investigation on the fireinduced hazards of Li-ion battery cells by fire calorimetry. Energy Environ. Sci., 2012, 5, 5271-5280.

[20] T. Xu, S. Hui, Combustion Science, China machine press, Beijing, 2017.

[21] Y. Zhang, H. Wang, W. Li, C. Li, Y. Ouyang, Size distribution and elemental composition of vent particles from abused prismatic Ni-rich automotive lithium-ion batteries. J. Energy Storage 26 (2019) 100991.

[22] Y Zhang, H Wang, W Li, C Li. Quantitative identification of emissions from abused prismatic Ni-rich lithium-ion batteries. eTransportation 2 (2019) 100031.

[23] PANDEY G, JAIN R, BUDHIRAJA $R$ et al. Phytoremediation: an overview of metallic ion decontamination from soil[J]. Applied Microbiology and Biotechnology, 2014, 61(56): 405-412.

[24] Dermont G, Bergeron, Mercier G M, Richer L M. Soil washing for metal removal: A review of physical/chemical technologies and field applications[J]. Journal of Hazardous Materials, 2008, 152(1):1-31.

[25] Ping Chen, Yan Chen, Lu Bai. Environmental quality standards for soil and state of soil pollution in Japan $[\mathrm{J}]$. Environmental Monitoring in China 20(4) (2004) 63-67.

[26] Bulletin of National Survey of Soil Pollution [EB/OL]. (2014-04-17). http://www.gov.cn/foot/site1/20140417/782bcb 88840814ba158d01.pdf.

[27] G. Zhuang, Current situation of national soil pollution and strategies on prevention and control, Soil and Ecological Environment Safety 30 (4) (2015) 477-482.

[28] J.Y. Hu, J.Y, Dai, Advance in studies on human distribution and toxic effects of perfluoroalkyl and polyfluoroalkyl substances, Asian J. Ecotoxicol. 8 (2013) 650-657.

[29] H. Wang, Y. Zhang, C, Li, W. Li, M. Ouyang. Venting process of lithium-ion power battery during thermal runaway under medium state of charge, Energy Storage Science and Technology 8(6) (2019) 1043-1048.

[30] Y. Lu, Soil Science, Beijing: China Agricultural Press, 2006.

[31] Reiner Korthauer. Handbuch Lithium-IonenBatterien. Beijing: China machine press, 2018.

[32] Taizhong Gao, Jingyin Li. Study on the heavy mental-contaminated soil and status of the treatment. Soil and Environmental sciences 8(2) (1999) 137-140. 
[33] Xiaonan Lu, Cifu Ment, Wanzhu Ma, Review on heavy metals, soil environment quality and food safety. Chinese Journal of Eeo-Agrieulture 15(2) (2007) 197-200. 